\title{
The Internet as business enabler
}

\section{Peter Hall}

Peter Hall Associates, South Africa

peterhall@icon.co.za

\section{Contents}

Introduction - the Internet as business enabler

Emerging e-commerce business model

Africa Internet connections

Enable the business for online selling

Integration is key

Summing up

References

Appendix A - Banking as an example

\section{Introduction - Internet as business enabler}

\subsection{E-commerce - overview}

www.whatis.com defines e-commerce as follows:

'E-commerce (electronic commerce or EC) is the buying and selling of goods and services on the Internet, especially the World Wide Web. In practice, this term and a new term, 'ebusiness', are often used interchangeably. For online retail selling, the term e-tailing is sometimes used.

E-commerce can be divided into:

- E-tailing or 'virtual storefronts' on Web sites with online catalogues, sometimes gathered into a 'virtual mall'

- The gathering and use of demographic data through Web contacts

- Electronic Data Interchange (EDI), the business-to-business exchange of data

- E-mail and fax and their use as media for reaching prospects and established customers (for example, with newsletters)

- Business-to-business buying and selling

- The security of business transactions.

\subsubsection{E-tailing or the virtual storefront and the virtual mall}


As a place for direct retail shopping, with its 24-hour availability, a global reach, the ability to interact and provide custom information and ordering, and multimedia prospects, the Web is rapidly becoming a multibillion-dollar source of revenue for the world's businesses. A number of businesses already report considerable success. As early as the middle of 1997, Dell Computers reported orders of a million dollars a day. By early 1999, projected ecommerce revenues for business were in the billions and the stocks of companies deemed most adept at e-commerce were skyrocketing. Apart from computer and network products, books (Amazon.com), gardening products (Garden.com), music on compact disks (CDNow), and office supplies (SuppliesOnline) were a few of the better-known e-commerce sites. By early 1999, even businesses that have always counted on face-to-face customer interaction were planning e-commerce Web sites and many businesses were planning how to coordinate in-store and Web store retail approaches. Meanwhile, new businesses based entirely on Web sales were being invented daily.

\subsubsection{Market research}

In early 1999, it was widely recognised that because of the interactive nature of the Internet, companies could gather data about prospects and customers in unprecedented amounts through site registration, questionnaires, and as part of taking orders. The issue of whether data was being collected with the knowledge and permission of market subjects had been raised. (Microsoft referred to its policy of data collection as 'profiling' and a proposed standard has been developed that allows Internet users to decide who can have what personal information.)

\subsubsection{Electronic data interchange (EDI)}

EDI is the exchange of business data using an understood data format. It predates today's Internet. EDI involves data exchange among parties that know each other well and make arrangements for one-to-one (or point-to-point) connection, usually dial-up.

\subsubsection{E-Mail, fax, and Internet telephony}

E-commerce is also conducted through the more limited electronic forms of communication called e-mail, facsimile or fax, and the emerging use of telephone calls over the Internet. Most of this is business-to-business, with some companies attempting to use e-mail and fax for unsolicited ads (usually viewed as online junk mail or spam) to consumers and other business prospects. An increasing number of business Web sites offer e-mail newsletters for subscribers. A new trend is ‘opt-in' e-mail in which Web users voluntarily sign up to receive e-mail, usually sponsored or containing ads, about product categories or other subjects they are interested in.

\subsubsection{Business-to-business buying and selling}

Thousands of companies that sell products to other companies have discovered that the Web provides not only a 24-hour-a-day showcase for their products but a quick way to reach the right people in a company for more information.

\subsubsection{Security of business transactions}

Security includes authenticating business transactors, controlling access to resources such as Web pages for registered or selected users, encrypting communications, and, in general, ensuring the privacy and effectiveness of transactions. Among the most widely used security technologies are SSL and RSA. Secure Electronic Transactions (SET) is an emerging industry standard.' 


\section{Emerging e-commerce business model}

The Internet has broken all the rules. The combination of evolving business drivers, changing customer demands and the evolution of enabling technology is producing a business revolution. Electronic connections are changing the way companies deal with partners, with information access, where services and speed are the key differentiators. In fact, Web connections make it critical to optimise business processes across enterprises, rather than just within an enterprise. Success depends on excellent client services and products for each individual client. Organisations are morphing from vertically integrated supply chains to interconnected eco-systems of suppliers and clients. Business models are quickly evolving such that companies are essentially letting their customers finance their growth (e.g. Dell), using negative working capital and negative asset intensity. Gone are the days when firms always 1 - raise capital for physical assets, 2 - hold large stocks of unsold inventory, and 3 use large amounts of working capital to operate and grow. However, likewise one must recognise that faster and easier access to information works two ways - while access to information gives clients more bargaining power, putting downward pressure on prices, vendors react by integrating their client's infrastructure. This not only lowers the buyer's transaction costs, and provides hard to replicate benefits, it also increases switching costs.

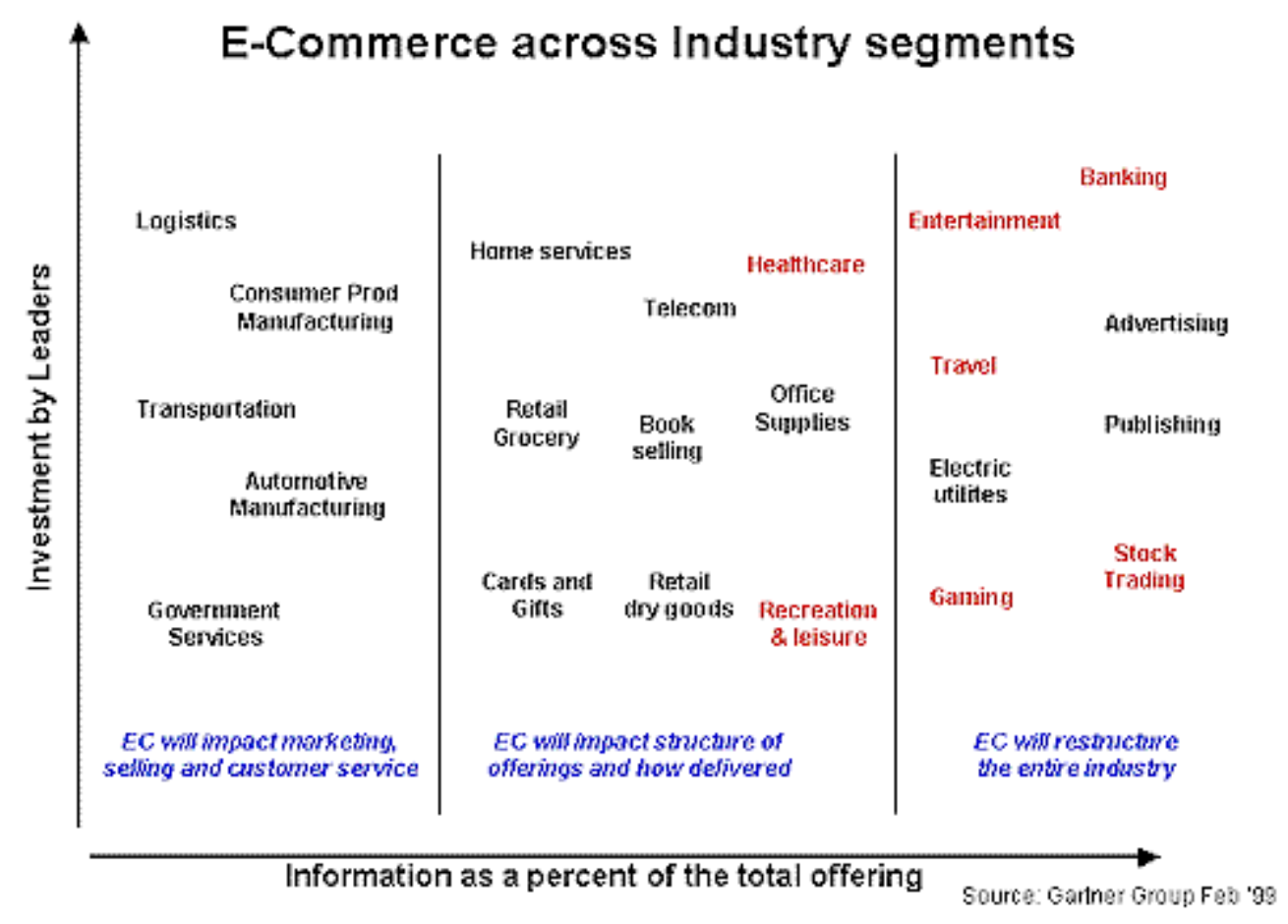

E-commerce will drive the massive restructuring of a dozen or more information-intensive and service-oriented industries, including entertainment, banking, travel, advertising, gaming, stock trading and utilities. E-commerce's impact differs depending on the processes, technologies and industries involved. The three types of impact diagrammed above are:

- In industries where the product or service is largely digital (e.g. advertising and entertainment), e-commerce can enable entirely new forms of products and services, as well as entirely new ways of delivering the value to the customer. This constitutes an entirely new industry structure and can dramatically upset the balance of power in the industry, creating new leaders from upstarts within a single year.

- In industries that are relatively consumer-focused (e.g. retail, grocery, 
telecommunications), vendors want to 'bypass' channel intermediaries and 'sell-direct' to end consumers. While eliminating weaker channels can be called 'industry restructuring'; it is not nearly as dramatic as what is possible in the first case.

- E-commerce has the least impact when physical goods are being delivered and the major task is to reconcile the delivery of goods and information. The larger and more expensive the goods, the fewer of them are produced, and the less importance eCommerce plays in restructuring the industry. For complex or larger capital-goods firms, e-Commerce can fulfil an augmenting role by ensuring accurate, complete and timely specification - for example, the Boeing project.

By 2002, 25\% of consumer spending and 70\% of business-to-business commerce (in developed economies) will be Web-involved ( 0.7 probability)

Through 2002, less than 15\% of e-commerce businesses that use the Internet as their exclusive marketing and sales channel will be profitable ( 0.7 probability)

Through 2002, global use of the Internet as a sales and marketing channel will lag US adoption rates by an average of 18 to 24 months ( 0.8 probability).

Source: Gartner Group - Feb ’99

\section{Africa Internet connections}

May 1996

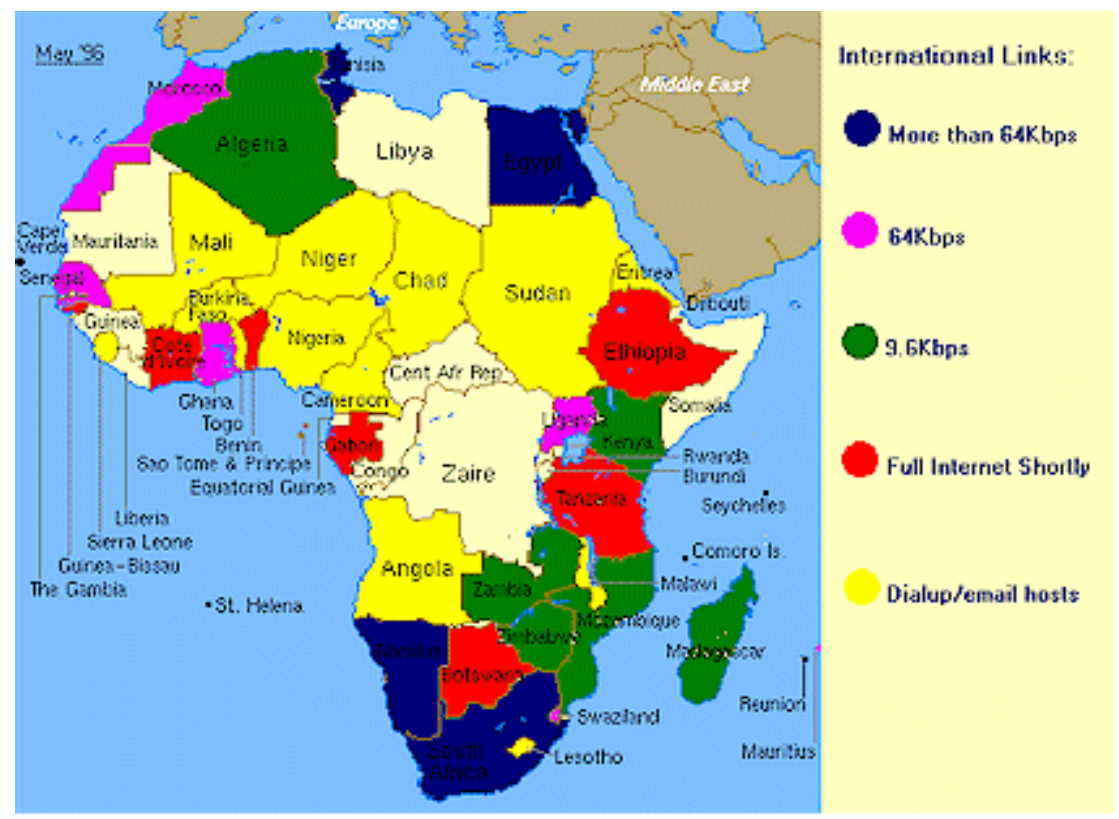




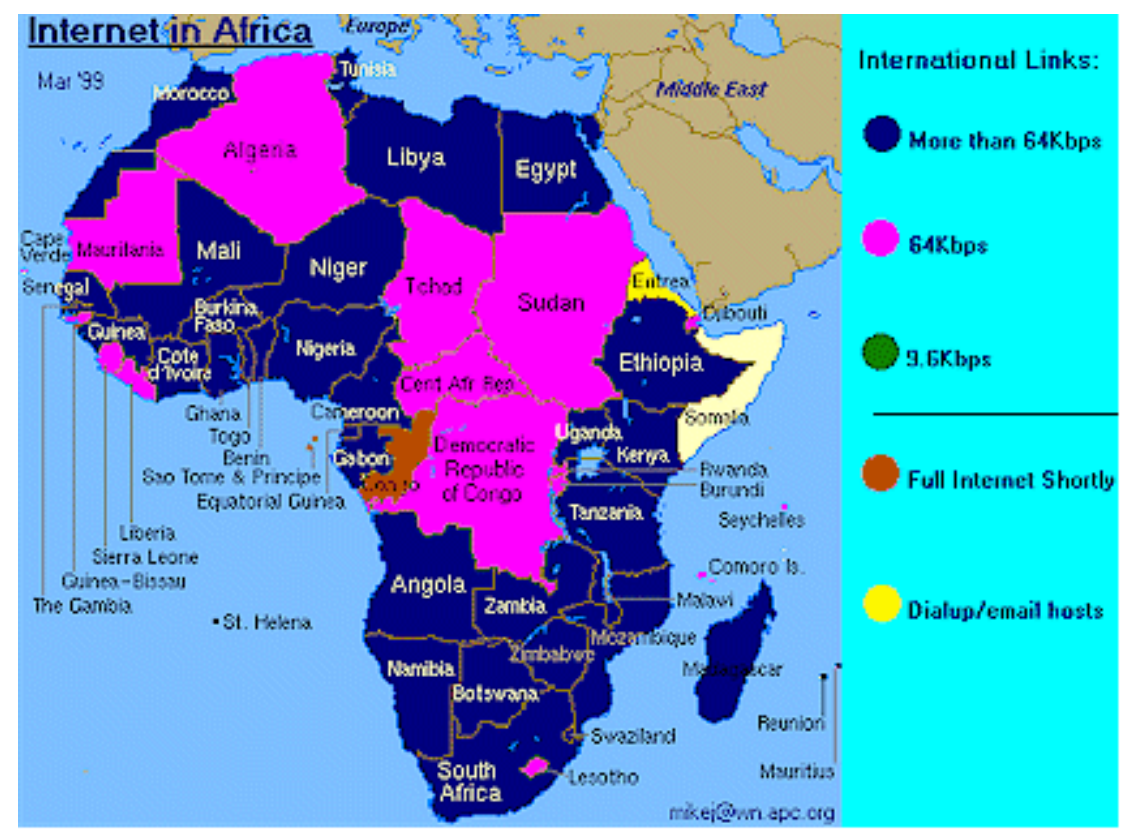

Top

\section{Enable the business for online selling}

I use the term 'store' generically to refer to any entity trying to sell products or services on the Web. So, if there are any bankers who feel offended by being referred to as a store, maybe you should rethink what you are offering or why you have a Web site.

I also assume that when you move into Web commerce you are serious about your commitment. Unlike a pathetic local site I visited some days ago which offered various commodities including a Dell laptop system which is at least 9 months out of date, no longer referenced on the Dell site and at a price that made my hair curl.

\subsection{Before you start - what are you getting into?}

The Web is a wonderful place, free of legislation; a place where anarchy rules. That is not to say that many have not tried to rule and influence the Web. Web behaviour has largely been defined and established by the users themselves without the heavy hand of central governments and commerce. This is very good news - long may it remain free of undesirable intervention.

- The Web levels the playing field. A high school can make a better Web site than a large industrial company.

- There are millions of consumers out there, but lots of other Web sites are competing for their attention. So you have to work hard to draw visitors to your site, work hard to create a site that those visitors want to buy from, and work hard to give those buyers such good service that they will buy again in the future and will talk about your great site and your great service.

- Starting a business on the Internet, or enabling existing business on the Internet is just like starting any other business - it needs the same level of planning, effort and commitment.

- The Web gives you something completely new: an inexpensive sales channel direct to consumers. Before the Web, if you wanted to sell direct to consumers, it was either brick and mortar, or catalogues, or flyers and the entry level cost was very high. 
- If you want to exploit the Web then do it right. Tatty Web selling and service is just like any other form of tatty selling and service, it won't work.

- This is not just about selling; it is also about the ubiquitous e-mail.

\subsection{Tips and Traps}

\subsubsection{Determine the scope of the project - choose your niche}

Be very clear why you are even considering this.

What sells online? Work does. Take two companies, A and B, that are selling the same products. A sells five times as much as B. Why? A works a lot harder. They work on their site almost every day, and they also do more to promote it.

As a general rule, you should be able to sell anything that the customer does not have to see and touch, in other words almost anything.

If you are going to target the local market check the latest local user profiles and statistics, if global sales are you ambition check global statistics.

The latest profiles for South African Internet users are as follows -

South Africa is currently the 16th most connected country on The Internet and although there are many surveys available, dealing with many issues, the focus of these 'world-wide' surveys is not localised enough.

What is the current typical profile of a South African Internet user?

Married male, aged between 26 and 30 and English speaking. He's well educated (has completed high school and is highly likely to be a university graduate) and earns between R10 000 and R19 000 per month. He uses Windows 95 as his operating system of choice and accesses The Internet equally from home and work. He's likely to work in the computer industry in one way or another and has been using The Net for a year or two.

\section{Access}

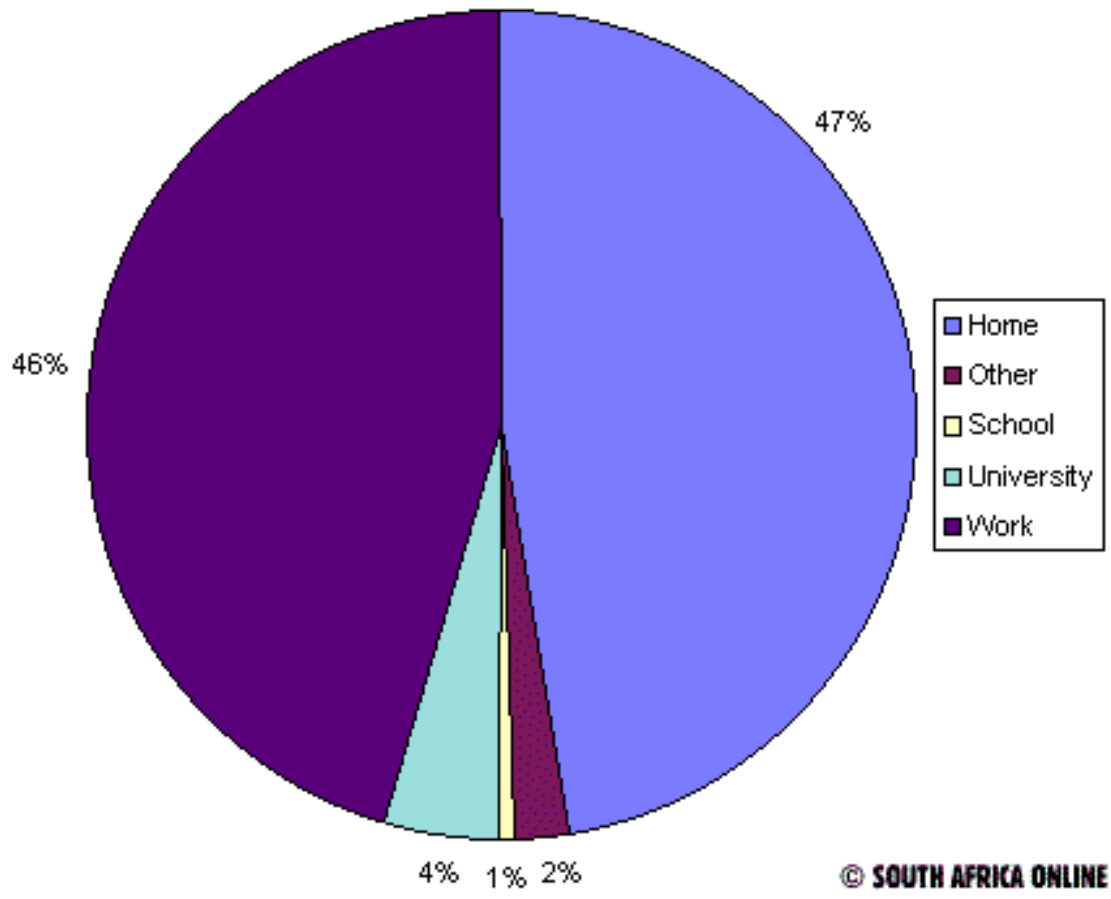

Education 


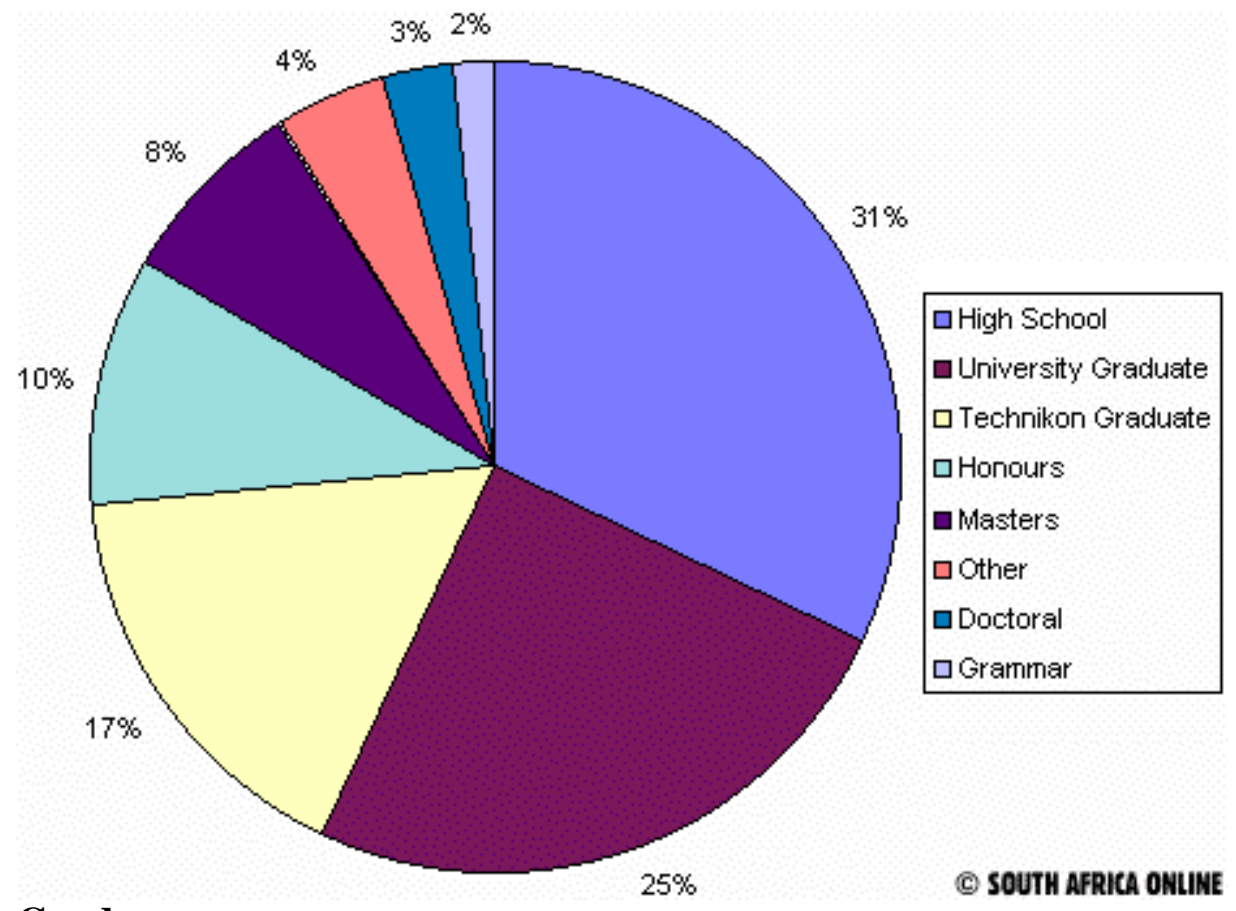

\section{Gender}

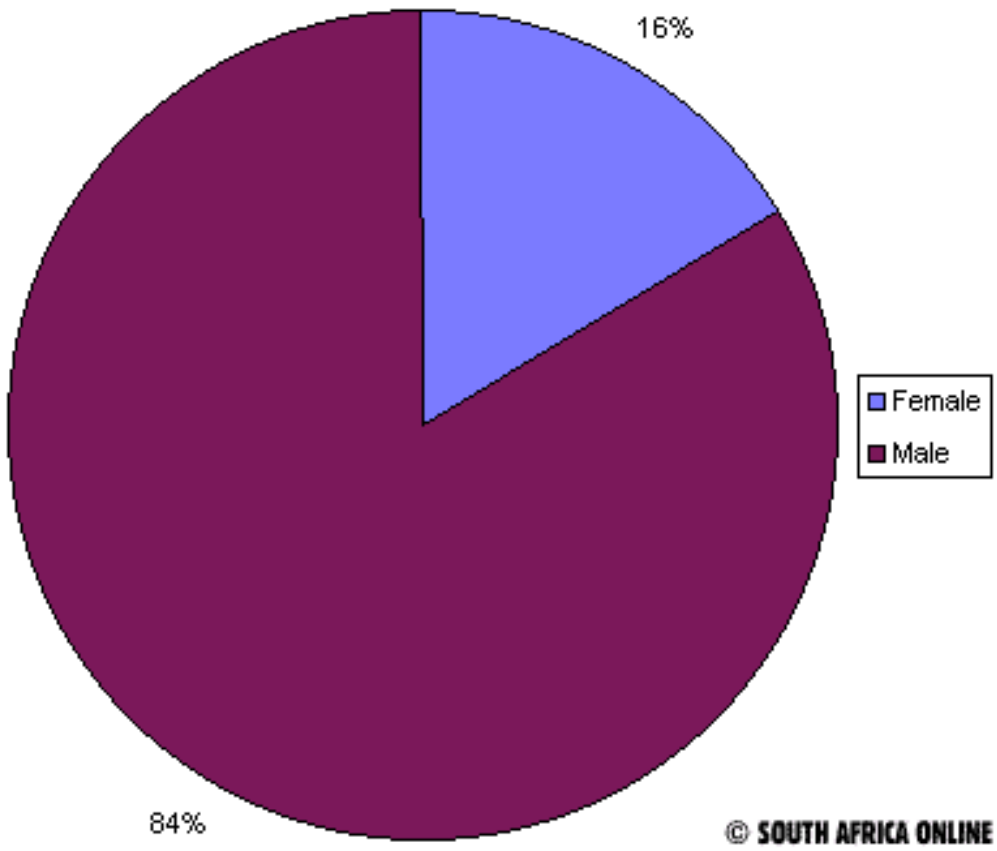

Monthly Income 

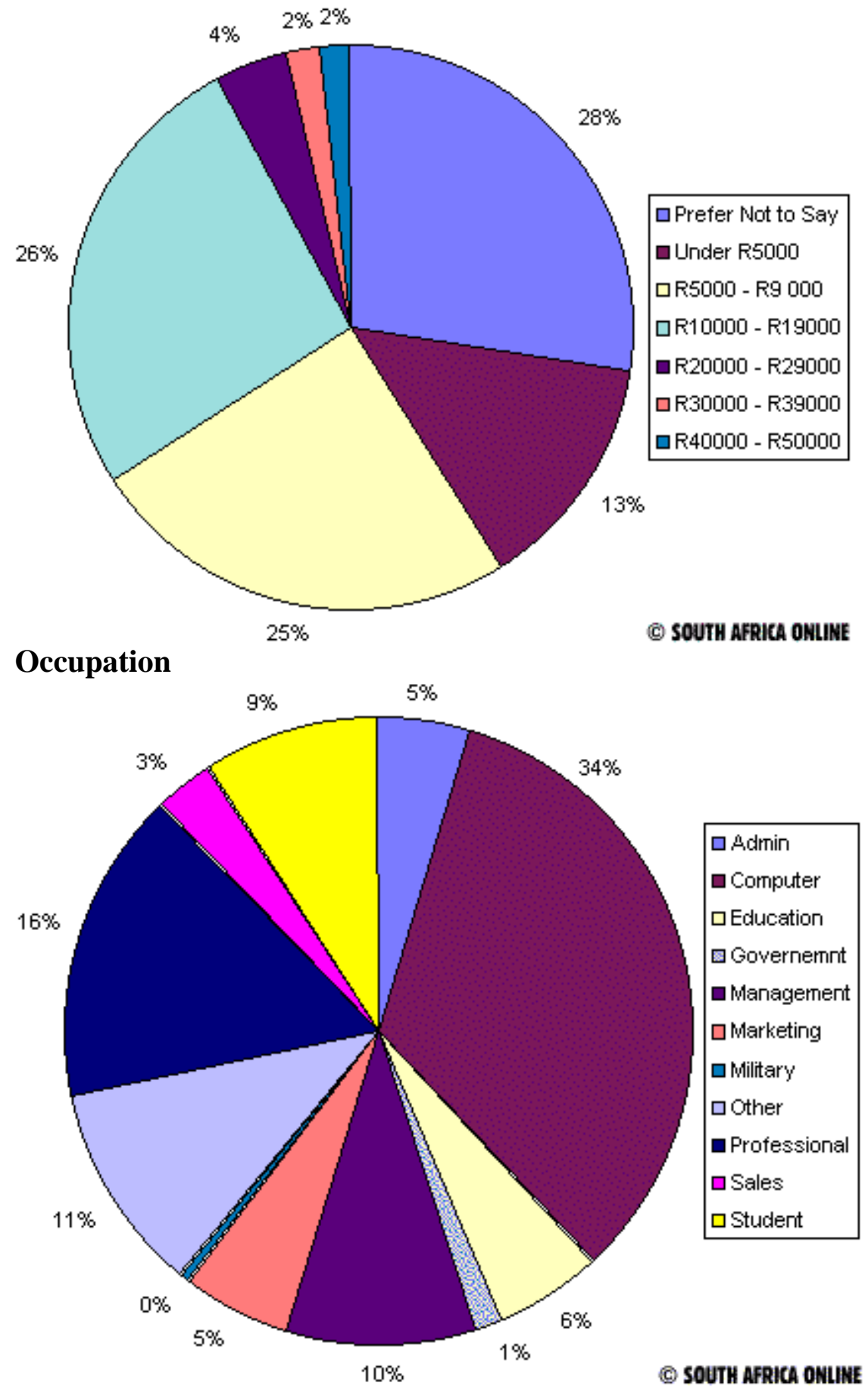

Marital status 


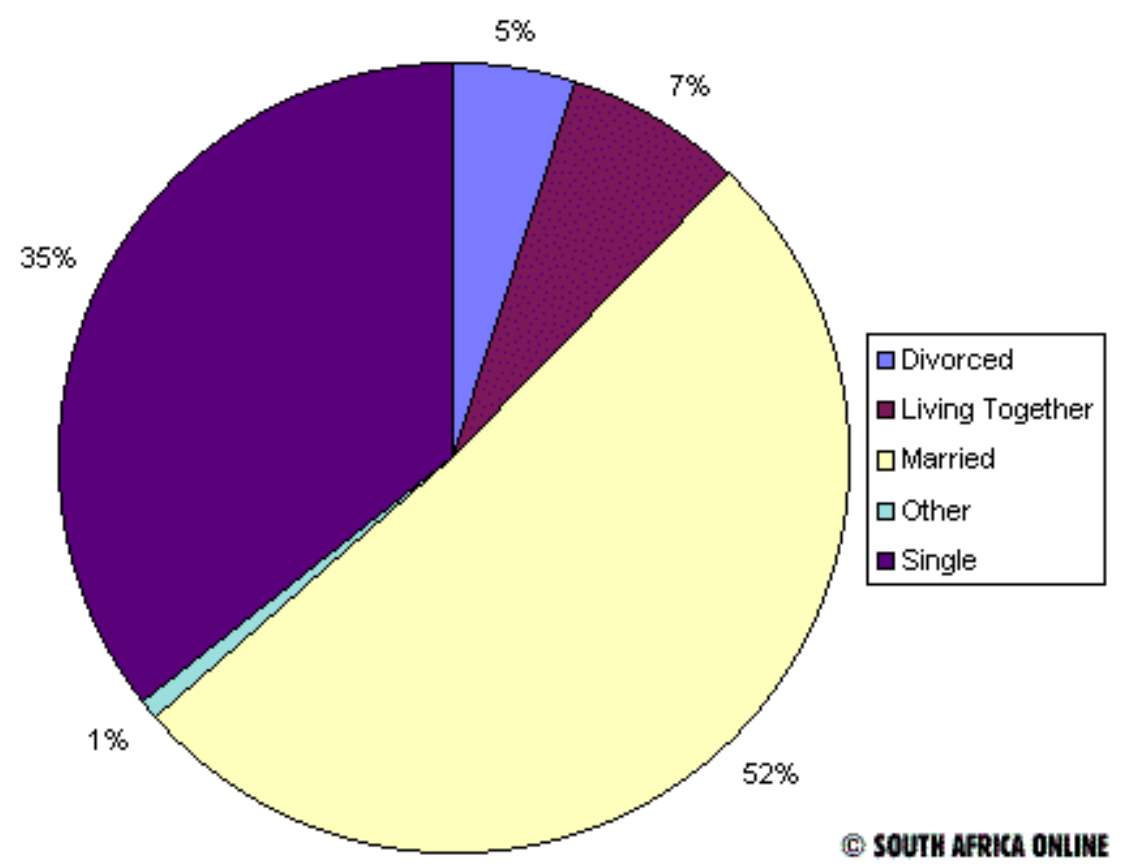

Copyright 1996, 1999 South Africa Online. All rights Reserved Source: The South African Internet Users' Survey; URL:

http;//www.southafrica.co.za/survey

It's true that more men use the Internet now than women, so if you sell something that men buy, you are likely to have a slight edge. Someone who works with computers is almost certain to have Web access, so anything computer-related is likely to do comparatively well. And Internet users are richer and better educated than the population as a whole, so luxury items may do well.

Geography is almost irrelevant on the Internet. Niches on the Internet are based on what you sell, not where you are.

Choose a niche that you can dominate, or choose a niche that offers special value. If you are a South African company and you want to dominate, it is going to be difficult to compete on normal Internet products - local CD store isn't going to knock CDNOW off it's pedestal. But how about becoming the site for African folk music, or the site for live African wildlife experience? Pay a visit to africam.com, you will notice that most of the 'photo of the day' winners are from the USA.

\subsubsection{What effect will this new sales method have on your existing marketing style and commitments? - avoid the 'me too' rush into oblivion}

If you are the manufacturer of a specific product you can gain great benefit from eliminating the channel - but beware, you may enrage your traditional end resellers and alienate your sales force. You will need to create a model that works for all your selected channels.

\subsubsection{Set Web site sales goals and budgets - this is work so be business-like}

Be conservative about profit expectations. The Web set up and acceptance will take time. This is not like opening a shop in a mall where the passing trade will automatically stream in. Budget for online marketing.

\subsubsection{Determine the level of Integration with existing company systems -} this could be the single most important thing you do, if you do it right 
Setting up a Web site with poor systems at home will be a disaster. What is the impact of offering product on the site that is out of stock, or of offering obsolete stock, or of being unaware of your customer's profile, or of failing to automate the purchase process or delivery process.

Amazon only opened their doors when they were sure they had the complete process automated. Those who have used Amazon will have experienced the order taken at midnight Amazon time which is processed fully in minutes with email confirmation of status. They may have experienced the failure of books to arrive and the high level of service to deliver a duplicate set without any question and at Amazon's expense. They will also have experienced the follow-up and suggested buys.

This does not happen with un-integrated systems both within the organisation and outside the organisation's doors with trading partners.

You have opened your kimono so be sure that what is now visible won't nauseate your visitors. Do you remember the first ATM systems and the very visible glitches? No more charming tellers to hand-off the 'system down' questions, you are now in the customer's face and as soon as they realise that you have done this to cut costs or to raise sales they will be intolerant of failure. Don't promote the 'convenience' angle too hard, most sophisticated customers can see through this ploy - they know you're in it for the money.

Give them a great deal both on product and service and they will return - don't integrate fully and you can't measure up to the promise.

\subsubsection{Decide whether e-selling will be developed internally or externally}

This is a decision that can make a success of the venture. As Forrest Gump said, 'would you cut your own hair?'

External is probably best for medium to large corporations. Although it may cost more, it works for the same reason that corporations use professionals to make TV ads.

You cannot find' retain and motivate highly specialised people to design, build and maintain top quality Web sites. Maintenance if vital to the continued success, don't assume that once the site is built you can take over maintenance, it may soon become ordinary.

Beware the propeller heads with little or no selling skills. Consider turning over the Web design and build project to your advertising agency, they know your business, they employ creative people and they understand selling.

\subsubsection{Establish a relationship with a bank for payments and test the payment collection system}

Set up a comprehensive test scenario and run many varied transactions through the payment system right into your selected bank.

Whilst this might be a normal system build process, you would be surprised how many Web sites just go live with inadequate testing.

\subsubsection{Establish security levels - there is still resistance - don't kiss and tell}

Security is very important, but you are entering a conflict zone between safety and convenience. Credit cards over the Internet are no more risky than over the phone, or in the 
hands of restaurant staff out of your sight. Credit card issuers generally have entered a contract with the user and will reject illegal transactions. Speak to your bank. They can be paranoid about security but they have good reason as the fraud numbers climb.

If you gather information about your customers let them know that you will keep it to yourself and then do so.

\subsubsection{Select a system/delivery combination powerful enough to service your offer}

If you are really lucky you have a wealthy investor and can start with a 'green field' approach. More likely is that you are adding a new channel to your existing business. This means supply-chain systems, integration, delivery, follow-up and management.

Most Web buyers are still reticent, so offer them real service. For example, guarantee that they will be satisfied with what they buy from you, or you will refund their money with no questions asked.

Your site should offer secure online ordering, and you should say so to visitors. But if you try ordering online yourself, you'll find the biggest concern that you have is not security. I bet what you'll find yourself thinking is, who are these guys? Did they actually get my order? Are they going to send me the products? When?

As the merchant, you should send the buyer an email thanking them for their order and telling them when the goods or services will arrive or be made available.

And make sure that you ship orders quickly. Web users want fast results. They don't want to hear that they should expect to wait 4-6 weeks for delivery. This is not 1910 . Tell them they will get their order in 3 days.

If a customer does send you mail, respond promptly! Customers who have taken the trouble to send you email are like gold. Talk about qualified prospects. So treat them like gold. If you can, make it a corporate policy to respond to email within an hour or two at most. You have to reply eventually, so why not do it right away? Customers will be delighted to see that you care about them. I sent an e-mail to my bank about three months ago to enquire about their Y2K readiness. You guessed it; I am still waiting for a reply. What conclusion should I draw, they don't care, they don't know me because their systems are so tired; or horror of horrors, they are not yet ready for Y2K? And I have been a customer for 25 years.

Delivery is a problem in South Africa. I can barely get a furniture shop to tell me which week a new bed will arrive, let alone which day or hour. And when it doesn't arrive on the appointed day, do I get a pro-active call to apologise and to offer to deliver at a specific time on the coming weekend. Not at all, I have to phone, chivvy, beg, throw my teddy out of the cot and hope that someone at the far end of the call is vaguely interested in my 'consumer' rage. We have much work to do - all that great Web selling can be undone by lack of delivery.

\subsubsection{Develop the content of your Web site very carefully - be real}

Always remember that your visitors are not physically in your store so anything you can do to make them feel relevant works.

Anything you can do to show that you are real will help increase interest. Include your name, phone number, and street address. Maybe even a brief company history, but keep it relevant 
to the selling process. Don't try to combine a sales Web site with a general interest Web site. Visit the Wells Fargo bank site - nearly all of the home page is sales related and immediate.

The best way to show that you mean business may be to include a full selection of products. One of the things that distinguishes players like Amazon and CDNOW is their huge inventories, which show that they are serious about selling online.

A surprising number of companies have online stores that send the opposite message. Some don't even have ordering working yet. It makes you wonder, do these guys actually want your business?

\subsubsection{Set up clean and clear navigation paradigms - keep it easy}

Overall the most important feature of a Web page is the organisation. That is what visitors will notice first. It should be possible to 'read' the structure of a page at a glance. A high quality Web site looks clear. A badly designed site looks haphazard.

Of the elements on the page, the most important are the images. A Web page consists of text and images, and everyone's text looks the same, so the difference in production values between good sites and mediocre ones depends almost entirely on images.

\subsubsection{Optimise the graphics - get it right, and target the majority}

- This is not intended as a dissertation on Web design, but Web design is critical to your success. Let's look at a few of the turn-ons and turn-offs which will impact how, or if you trade.

- There is no direct connection between the quality of your site and the quality of your company. A company could have a brilliant graphic designer and lousy products. But usually there is a connection, and that is what visitors to your site will assume. If your company is unable to put up a good Web site, then it seems natural to assume that your company cannot deliver good products or services.

- What makes a site say that? The same thing that makes a Ferrari look like it means business: good design. On the Web, good design means good proportions, appropriate typefaces, clear layout, and colour combinations that work.

- Make sure the designer has built a site for the majority, avoid techniques that restrict your viewing public.

- It is no accident that the people who visit your site are called 'Web surfers'. They have the same short attention span as TV 'channel surfers'. The average visitor to a Web site looks at only three or four pages before going somewhere else. Visitors will leave at the slightest obstacle.

- So if you want people to visit and order from your site, don't put any obstacles in their way. Whatever you do, don't force visitors to register.

- There should be no bells and whistles to distract your visitor. The design of the site should be so simple that they get it at a glance.

- Many of your visitors will not start at your front page. Many of your hits will come from search engines, and when someone searches for a phrase in a search engine, they are sent directly to the page in your site that contains that phrase. So most of your visitors will drop right into the middle of your site, like paratroopers. The design of your site has to tell them immediately where they are, and what their choices are.

- Many of the people who arrive at your site will be searching for a specific product, so pay special attention to them visitors, because they are the 
ones who actually spend money.

\subsubsection{Web site promotion, develop an aggressive plan}

You've built a great site, now where are all the buyers?

Promoting an online store is different from promoting an ordinary Web site. You want sales.

Try being a buyer. Decide what you are looking for and then try to find it. Where do I start looking?

A year ago, there was no definite answer. Maybe a search engine. Maybe a site related to the kind of stuff you sell. The biggest source of traffic is probably still general-purpose Web searches.

While there are software products and services that help you to submit your site to hundreds of search engines and indices. There are only eight that matter: Yahoo!, AltaVista, Excite, MSN, WebCrawler, Infoseek, HotBot, and Lycos. All other search engines and indices might account for $1 \%$ of your hits, combined.

Which sites should you get links from? Put yourself in your customer's position. If you are selling Star Trek merchandise, go to Yahoo! and search for 'star trek'. The sites you get sent to are the same ones your customers will be sent to, so those are where you want to start asking for links.

Use banner ads but be sure you use them in the right place. Yahoo reports on one online store that bought a banner ad on Playboy's Web site. They don't disclose the company name, but let's say they were selling modems. Most of their buyers were men, and they knew that thousands of men visited Playboy's site, so where better to put an ad? And in fact, they did get thousands of visits from this banner. But not one order. Why? Well they didn't visit Playboy to buys modems, did they?

Finally, do your homework, know your target.

\subsubsection{Test your Web site - then test it again and then again.....}

Well this is obvious, isn't it? Isn't it? Found any spelling mistakes on a Web site lately, found links that don't work, found any offers that are no longer valid?

Would you behave like this at the mall?

\subsubsection{Go live - wow, big day - if you haven't done the other stuff right this will be a big bad day}

Take time and effort to activate your Web site by setting up information on search engines and by whatever advertising means you have selected. This does not happen overnight.

Don’t rush to open your doors until you are ready.

Then fanfare - let the world know you are there.

\subsubsection{Update - be new, be innovative - don't let it go stale - differentiate}


Price

The emotional satisfaction of getting something at the cheapest price is almost like a drug. People will go to any length to get it. If you want to see online commerce happen, take some commodity item like a Sony Walkman and offer it for sale on the Web for R50 less than people can get it anywhere else.

Amazon Books has done that, and now they have every prospect of being the place to buy books online. If Borders and Barnes \& Noble are not panicking, they should be. They waited too long. Someone else has occupied the space they thought was reserved for them, and it's going to be very expensive, and perhaps even impossible, to dislodge them.

\section{Change}

Big department stores seem to know that a certain amount of bustle is necessary to show that they are alive. They are constantly changing their displays.

Overall, the more time a company spends on its online store, the better it tends to do.

So you should be constantly improving your site. And even if you think your site is perfect, you should still change it regularly. A Web site that has not changed for months is boring. It feels abandoned. Have you ever visited a store in a remote area where the turnover is obviously very low? Where the items on the shelves are faded, or have dust on them? Do you want to buy from a store like that?

Fortunately, with the latest generation of Web building tools, it is easy to change your site regularly.

\subsubsection{Monitor - reshape marketing and structure - the Web moves very fast}

You have the tools to monitor customer visits, so use them to send off a 'we've missed you' e-mail.

Use the information you have about your customers to customise the message. If he is a 90 year old who visited your store to buy a walker, think before offering him a great new deal on a surf board.

Last year Amazon sent out coffee mugs to their better customers, horrid plastic thing, but at least they knew my habits and where to find me. When was the last time you received a real 'thank you for your business' from your bank, rather than a sales brochure masquerading as a thank you?

\section{Integration is key}




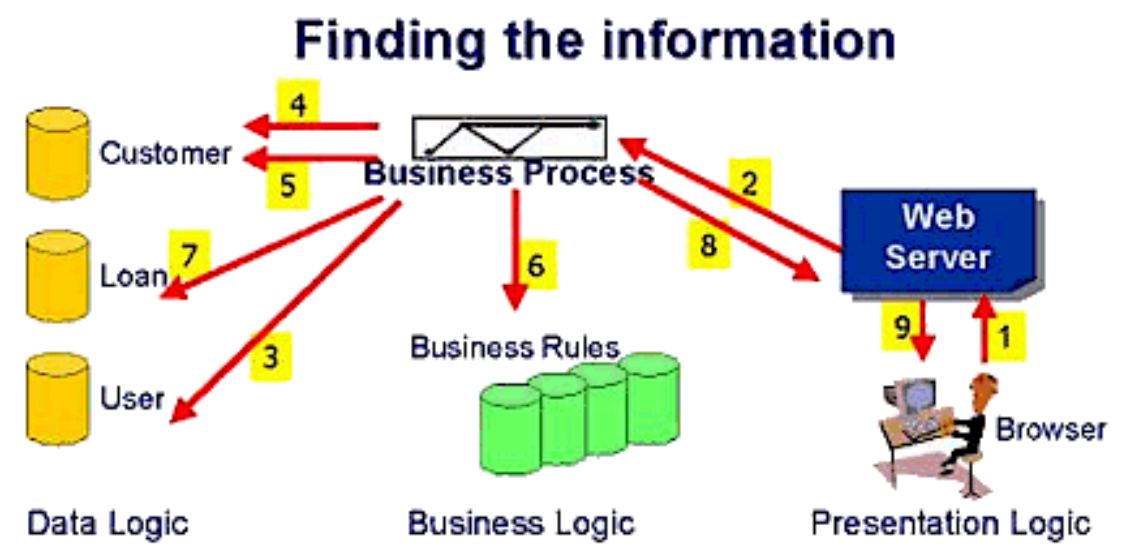

1. User Initiates Loan Application Process

2. Start Loan Application Business Process

3. Verify User

4. Locate Customer

6. Invoke Business Rule

If Lown Amount $>1,000,000$ Then

Decline

Else

7. Create Loan

5. If Customer does not Exist Then

8. Reply Successful

Add Customer

9. Send Successful Screen

Reference: Advanced Network Solutions (Pty) Ltd

The Web site is the shop front. The back-end systems are the company lifeblood. Integration is the single most important thread running through the Web integrated business offer. It is application integration that allows islands of information to interact, that allows application silos to be conjoined to provide a full service.

It is integrated systems that allow Amazon to get an order at midnight, process the order, check payment, check delivery, etc. and e-mail a confirmation to the buyer within seconds. Not just systems under their own control, but also systems outside their front-door.

\section{Summing up}

\subsection{Myths and some near myths}

Vic Keegan of the Guardian $19^{\text {th }}$ August 1999 has offered three great myths of the Internet which I have used to suggest where we might be heading.

\subsubsection{Great myth no. 1}

The Internet has ushered in a dematerialised or 'weightless' world. Phooey.

Every time you buy a product you will end up receiving the product just as you did before but what about the new delivery mechanisms that must be set up and controlled. If Pick 'n Pay introduced online shopping it will mean more jobs and more investment in vehicles for the delivery of goods you would otherwise have picked up yourself.

Practically everything you do on the Internet leads to more jobs and more products. Witness the success of Cisco, which makes routers to guide Internet communications.

\subsubsection{Great myth no. 2}


The first movers have a permanent comparative advantage. Nonsense. It is more likely that the reverse if true. It is not the pioneers that win, but those that follow and can gain from the mistakes of the pioneers.

Dell, Compaq and Gateway were not the pioneers in the PC revolution, but they are the winners now. Microsoft made its fortune exploiting products invented by others.

Amazon.com, whilst very prominent, is feeling the force of competition from rival booksellers forcing them to cut margins still further.

\subsubsection{Great myth no. 3}

The Internet increases efficiency by destroying the middleman. Should be true, but practice is not matching theory.

Amazon.com is the world's biggest bookstore and last week Homestore.com set up in the USA as the biggest online estate agent. Both have set up a network of resellers.

The moral is that no one yet knows where the Web is going and it is barmy to lay down iron laws about a phenomenon barely five years old whose main characteristic is an ability to change direction overnight.

Management gurus are already eating their words about recent theories like downsizing and re-engineering. But that is nothing compared to how wrong they will be about their Web models.

There is no doubt that the Internet is the most powerful force for change this century and that vast fortunes will be made. But not necessarily by the prime movers.'

\subsection{South Africa - a brief view of the future}

South Africa is a follower. It is generally accepted that we are 18 to 24 months behind the developed economies. Nevertheless, we have an economy that takes quite readily to technology. It is also an economy of extremes, not least of which is the availability of Internet connections to the public at large.

Cell phones have created an opportunity for South Africa to leap frog over recent developed economy technologies. Clem Sunter speaks of small phone shops that have been set for customers to can make a phone call for a maximum time for a fixed fee using one of the provided cell phones which are chained to the floor. These have been set up in areas where there is no cable infrastructure and have created a fine means of communication.

Could we see the same leap frog effect with the Internet? Friends recently set off to drive through Africa to England and we have been regularly entertained with their e-mails. The Lonely Planet Africa guide lists the Internet cafes one may find throughout Africa. It could be a small step from e-mail to e-ordering.

Caveat or opportunity? A top notch delivery service could make a difference.

\section{References}


'Electronic Selling' by Jamison, Gold, Jamison - McGraw-Hill.

'Blur: The speed of Change in the Connected Economy' by Christopher Meyer, Stan Davis.

South Africa Online. The South African Internet Users' Survey.

Gartner Group - South African conference - Feb. 1999.

Advanced Network Solutions.

\section{Selected links:}

Yahoo.com

Whatis.com

Wellsfargo.com

ABSA.com

Amazon.com

MessageQ.com

ItWeb.com.

\section{Appendix A}

Banking as an example

Barclays Bank in UK

Extensive services - FREE

Special offer - free Internet service

Simple and clear Web site.

Wells Fargo

Home page is product rich, not designer rich

Extensive services FREE if you maintain a minimum balance

Simple and clear Web site

Special offers for a range of things, some not even banking related

Easy demo - you can get to online banking in about one step

Full products list.

Local banks

Typically charged - complex charge structures

High graphics, one offers high or low graphics and then gives low graphics whatever you

choose

Online information and demo are down some levels

Selling to existing customers, no apparent attempt to gain new customers

Huge amounts of company information which is vitally important if I am a potential investor, but of very limited use if I am a product or service buyer.

\section{Disclaimer}

Articles published in SAJIM are the opinions of the authors and do not necessarily reflect the opinion of the Editor, Board, Publisher, Webmaster or the Rand Afrikaans University. The user hereby waives any claim he/she/they may have or acquire against the publisher, its suppliers, licensees and sub licensees and indemnifies all said persons from any claims, lawsuits, proceedings, costs, special, incidental, consequential or indirect damages, including damages for loss of profits, loss of business or downtime arising out of or relating to the user's use of the Website. 
ISSN 1560-683X

Published by InterWord Communications for the Centre for Research in Web-based Applications, Rand Afrikaans University 